\title{
COMPARISON OF METHODOLOGIES FOR CONIDIA PRODUCTION BY Alternaria alternata FROM CITRUS
}

\author{
Daniel D. C. Carvalho ${ }^{1}$; Eduardo Alves ${ }^{1 *}$; Tereza R. S. Batista ${ }^{2}$; Renato B. Camargos ${ }^{1}$; Eloísa A. G. L. Lopes ${ }^{1}$ \\ ${ }^{1}$ Departamento de Fitopatologia, Universidade Federal de Lavras, Lavras, MG, Brasil; ${ }^{2}$ Centro Universitário de Lavras, \\ Lavras, MG, Brasil.
}

Submitted: November 10, 2007; Returned to authors for corrections: April 04, 2008; Approved: November 02, 2008.

\begin{abstract}
Conidia production is a problem in the study of Alternaria alternata from citrus. Thus, this study aimed to compare existing methodologies for conidial production of $A$. alternata isolated from Ponkan tangerine (2 isolates), Cravo lemon ( 1 isolate), Pêra orange ( 2 isolates) and Murcott tangor (1 isolate). The methodologies used were conidia production with 12 and 24 hours under white fluorescent light, evaluation with 24 and 48 hours after applying fungal mycelium stress technique, cold stress followed by injury of mycelium and evaluation with 24 hours, using healthy vegetable tissue and the use of black fluorescent near ultraviolet (NUV) lamp. Satisfactory result was obtained with A. alternata isolate from Murcott tangor, with the production of $2.8 \times 10^{5}$ conidia $\mathrm{mL}^{-1}$, when fungal mycelium was stressed (Petri dish with $66.66 \%$ of fungi growth) and subsequently $24 \mathrm{~h}$ of growth. The use of white light $(24 \mathrm{~h})$ and black fluorescent NUV lamp also induced expressive conidia production by one isolate of Ponkan tangerine, which produced $17.2 \times 10^{5}$ and $10.1 \times 10^{5}$ conidia $\mathrm{mL}^{-1}$ and another of Murcott tangor, which produced $13.9 \times 10^{5}$ and $10.1 \times 10^{5}$ conidia $\mathrm{mL}^{-1}$, respectively. The remaining methodologies analyzed in this study were not able to induce conidia production in satisfactory quantity. The use of both mycelium stress technique and white light $(24 \mathrm{~h})$ and black fluorescent NUV lamp allowed the production of enough quantities of conidia to be used in vitro (detection of fungitoxic substances) and in vivo (pathogenicity test) assays, respectively.
\end{abstract}

Key words: Alternaria brown spot, mycelium stress technique, Murcott tangor, Ponkan tangerine, black fluorescent NUV lamp.

\section{INTRODUCTION}

Alternaria brown spot (ABS) is a most serious disease of many tangerines and their hybrids in humid and semiarid areas of citrus cultivation around the world (26). In Brazil, ABS was first found in Rio de Janeiro State (9) and subsequently became widespread in the major citrus area in São Paulo State (15). During the year of 2006, besides those states, this disease was found in many regions of Minas Gerais State, causing injury to Ponkan tangerine and, especially, to Murcott tangor (18). According to Peres and Timmer (16), the disease produces black necrotic lesions on young leaves, twigs, and fruit. On leaves, lesions may expand easily due to the production of a host-specific toxin by the pathogen, resulting in leaf drop and twig dieback, in most cases. On fruits, which are very susceptible to ABS, a dry up occurs and lesions vary from small dark necrotic spots to large sunken pockmarks, reducing their value for the fresh fruit market (31).

The causal agent of ABS was originally described as Alternaria citri Ellis \& Pierce, but further molecular studies showed that all small-spored isolates from citrus were similar. As consequence, they were designated as A. alternata f.sp. citri (Fr:Fr) Keissl (14). Thus, one host-specific pathotype causes disease in tangerines and their hybrids, another pathotype is specific to Rough lemon and Rangpur lime (13).

Since conidia production by some A. alternata isolates in culture media requires special techniques $(3,30)$, simple methods

*Corresponding Author. Mailing address: UFLA - Departamento de Fitopatologia, Caixa Postal 3037, cep 37200-000, Lavras, MG, Brasil. Tel.: 55 35 3829-1789, Fax: 5535 3829-1795. E-mail: ealves@ufla.br 
to do so are greatly welcome $(2,16)$. Thus, as part of a project aimed to carry out several studies with such fungus, this work was directed towards the establishment of a new methodology to easily obtain A. alternata conidia in a culture medium.

\section{MATERIALS AND METHODS}

\section{Fungal isolates}

First, fruit peel from symptomatic Murcott tangor, Ponkan tangerine, Pêra orange and Cravo lemon as well as Pêra orange leaves showing symptoms of ABS, were washed in tap water. Then, pieces $\left(10-25 \mathrm{~mm}^{2}\right)$ of these materials were subsequently immersed in 70\% ethanol (30-60 s), $2 \%$ sodium hypochlorite (30$60 \mathrm{~s})$ and distilled water $(2 \times 30 \mathrm{~s})$. Four fragments of each material were placed in a Petri dish containing $13 \mathrm{~mL}$ of Potato-DextroseAgar (PDA) (200 g cooked potato, $20 \mathrm{~g}$ dextrose and $20 \mathrm{~g}$ agar in $1 \mathrm{~L}$ distilled water). After seven days at $25^{\circ} \mathrm{C}$, under photoperiod of $12 \mathrm{~h}(19)$, agar plugs $(9 \mathrm{~mm})$ with fungal mycelium were transferred to new PDA Petri dishes for fungus purification. The isolates obtained and used in this study are presented in Table 1.

Table 1. Isolates of A. alternata from citrus used for the evaluation of conidia production.

\begin{tabular}{ccc}
\hline Source of isolate & Part of the plant & Isolate code \\
\hline Cravo lemon & Fruit & B-66-01 \\
Murcott tangor & Fruit & A1-03-04 \\
Pêra orange & Fruit & B-52-09 \\
Pêra orange & Leave & A-07-01 \\
Ponkan tangerine & Fruit & B-52-01 \\
Ponkan tangerine & Fruit & B-62-04 \\
\hline
\end{tabular}

\section{Pathogenicity assay}

Ripe and healthy Murcott tangor fruits, Pêra orange, Ponkan tangerine and Cravo lemon were washed with water and soap and left to dry during $60 \mathrm{~min}$. Under aseptic conditions in a laminar flow chamber, four equidistant points were selected around the point of insertion of the fruit with plant. Four perforations ( $3 \mathrm{~mm}$ deep) were made with a needle on each selected point and agar plugs $(6 \mathrm{~mm})$ with fungal mycelium of B-66-01, B-52-09, A-07-01 and B-52-01 isolates was placed on each point in the fruit (7). Isolates A1-03-04 and B-62-04, which were able to produce conidia, were inoculated through $20 \mu \mathrm{L}$ of an aqueous spore suspension at $10^{6}$ conidia $\mathrm{mL}^{-1}(5)$. The inoculated fruits were kept in a moist chamber at $25^{\circ} \mathrm{C}$, under a $12 \mathrm{~h}$ photoperiod. After 12 days, symptoms of ABS were verified and the pathogen was re-isolated. The frequency of plant pathogenic fungi was expressed as the percentage of fruits in which the fungus was isolated and the pathogenicity was confirmed (7). Six fruits were used per isolate and the control treatment comprised six fruits in which no fungal inoculation was applied, but only $1 \%$ Tween 80 .

\section{Conidia production with 12 and 24 hours of daylight fluorescent lamp}

Agar plugs $(9 \mathrm{~mm})$ from purified fungus were transferred to PDA plates and after 7 days, under temperature of $25^{\circ} \mathrm{C}$ and photoperiod of $12 \mathrm{~h}$ (Philips daylight fluorescent lamp, 20W, TLT, 75RS), the conidia production was evaluated (A). In (B) the same methodology was applied, but the photoperiod was $24 \mathrm{~h}$ of constant light.

\section{Evaluation with 24 and 48 hours after fungal mycelium stress technique}

Agar plugs $(9 \mathrm{~mm})$ of purified fungal colonies were transferred to plates and after 7 days, under temperature of $25^{\circ} \mathrm{C}$ and photoperiod of $12 \mathrm{~h}$, the mycelium stress technique was carry out by the introduction of a needle into the colonies at $4 \mathrm{~mm}$ deep. Briefly, needle was used to make cuts in the colonies from Petri dish with $66.66 \%$ of growth. Thus, a grid with blocks, $7 \mathrm{~mm}$ length, was obtained in the mycelium. The Petri dishes were incubated at conditions mentioned before and after $24 \mathrm{~h}(\mathrm{C})$ and $48 \mathrm{~h}(\mathrm{D})$, conidia production was evaluated.

\section{Cold shock followed by injury of mycelium and evaluation after 24 hours}

Fungal cultures produced as in the methodology (A), without the application of mycelium stress technique in the same plate, were grown for 7 days, at $66.66 \%$ of dish area. After, Petri dishes were transferred to refrigerator, where were kept by $24 \mathrm{~h}$ at 5 $8^{\circ} \mathrm{C}$ and without light. Immediately after, the dishes were submitted to mycelium stress technique and transferred to another incubator and after $24 \mathrm{~h}$ at $25^{\circ} \mathrm{C}$ and photoperiod of 12 $\mathrm{h}$, they were evaluated regarding conidia production by using a Neubauer chamber (E).

\section{Conidia production on citrus plant tissue}

Fungal cultures submitted to methodology (A), without mycelium stress technique, were used to originate agar plugs ( 9 $\mathrm{mm}$ ) with fungal mycelium. The agar plugs were transferred to new PDA plates and incubated during 5 days, sufficient for the colonization of $50 \%$ of the Petri dish area. After that, pieces from fruits and leaves of autoclaved citrus tissue $\left(1 \mathrm{~cm}^{2}\right)$, of the same species to which the strains was obtained were transferred to PDA plates, next to fungal growth border (F). After 4 days of fungal growth on plant tissues, part of mycelium was removed from the dishes to make microscope mounting using glycerol $50 \%(\mathrm{v} / \mathrm{v})$ and conidia production was evaluated.

\section{Conidia production by the use of black fluorescent NUV lamp}

For the stimuli of conidia production, a methodology developed by Bóveda (3) was used. It was based on the fungus 
growth on PDA by 7 days, at $25^{\circ} \mathrm{C}$ and photoperiod of $12 \mathrm{~h}$ with daylight fluorescent lamp mixed with black fluorescent NUV lamp (Ecolume/NUV, 20W, FL, T-8/BLB) (G). In addition, the fungal colonies were submitted to mycelium stress technique after 7 days of incubation on black fluorescent NUV lamp, and after $24 \mathrm{~h}$, conidia production was evaluated using a Neubauer chamber $(\mathrm{H})$. The methodology (I) was identical to the $(\mathrm{H})$, excepting incubation time post stress, which was $48 \mathrm{~h}$. A summary of methodologies employed is shown in Table 2.

\section{Evaluation of conidia production on Neubauer chamber}

In all methodologies, excepting (F), $10 \mathrm{~mL}$ of $1 \%$ Tween 80 (g $\mathrm{mL}^{-1}$ ) autoclaved solution were added and dispersed with glass rod into Petri dishes followed by filtration. The number of conidia was determined with a Neubauer chamber in a light microscope (2). All tests were conducted with 4 replicates.

\section{Light microscopy (LM)}

Part of mycelium was removed from dishes to make microscope slides mountings using glycerol $50 \%(\mathrm{v} / \mathrm{v})$ and the morphology of the fungus was observed using a Leica DME light microscope.

\section{Statistical analysis}

Analysis of variance was applied for the data obtained in all methodologies, without any transformation. The Scott-Knott (22) test $(\mathrm{P} \leq 0.05)$ was applied.

\section{RESULTS}

Symptoms of Alternaria brown spot were observed in all inoculated fruits (Fig. 1), but not on fruits inoculated only with $1 \%$ Tween 80 .

Among the 6 isolates studied, Murcott tangor (A1-03-04) and Ponkan tangerine fruits (B-62-04) produced considerable amounts of conidia when the mycelium stress technique, fluorescent light white lamp ( $24 \mathrm{~h}$ ) and black fluorescent NUV lamp were used (Table 3). Also, some conidia production was obtained with the use of thermal shock. Quantity of conidia considered enough to carry out fungi toxic substances
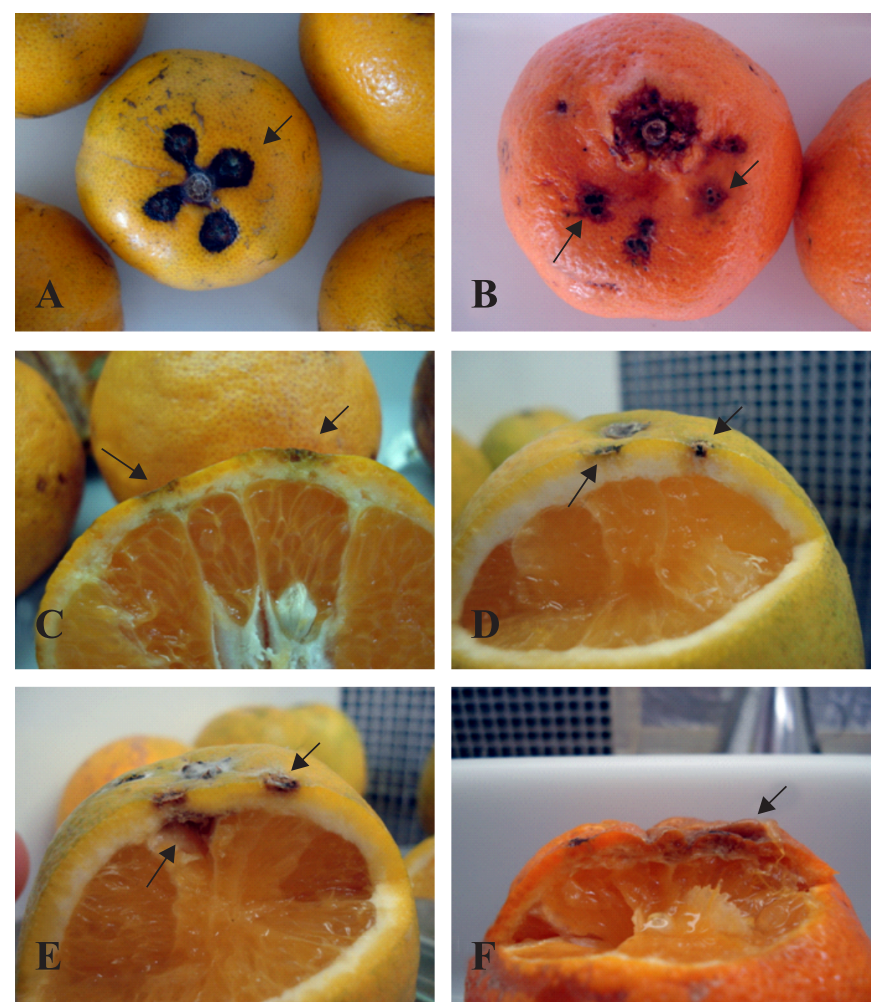

Figure 1. (A - B) Murcott tangor and Ponkan tangerine fruits inoculated with conidia, and (C - F) Ponkan tangerine, Pêra orange and Cravo lemon fruits inoculated with mycelium of Alternaria alternata, evaluated 12 days post-inoculation. (A) Murcott tangor (A1-03-04); (B) Ponkan tangerine (B-62-04). (C) Ponkan tangerine (B-52-01); (D) Pêra orange (B-52-09); (E) Pêra orange (A-07-01); (F) Cravo lemon (B-66-01).

Table 2. Methodologies employed to conidia production.

\begin{tabular}{cc}
\hline Methodology & Summary \\
\hline A & Conidia production with 12 hours of daylight fluorescent lamp. \\
B & Conidia production with 24 hours of daylight fluorescent lamp. \\
C & Evaluation with 24 hours after fungal mycelium stress technique. \\
D & Evaluation with 48 hours after fungal mycelium stress technique. \\
E & Cold shock followed by injury of mycelium and evaluation after 24 hours. \\
F & Conidia production on citrus plant tissue. \\
G & Use of black fluorescent NUV lamp during 7 days. \\
H & Use of black fluorescent NUV lamp, followed by mycelium stress and evaluation after 24 hours. \\
I & Use of black fluorescent NUV lamp, followed by mycelium stress and evaluation after 48 hours.
\end{tabular}


Table 3. Average number of Alternaria alternata conidia $\mathrm{mL}^{-1 *}$ and coefficient of variability (CV) after the application of the methodologies (A), (B), (C), (D), (E), (F), (G), (H) and (I) to the stimulation of in vitro conidia production.

\begin{tabular}{cccccccc}
\hline \multirow{2}{*}{ Methodology } & $\begin{array}{c}\text { Cravo lemon } \\
\text { fruits }\end{array}$ & $\begin{array}{c}\text { Murcott } \\
\text { tangor fruits }\end{array}$ & $\begin{array}{c}\text { Pêra } \\
\text { orange fruits }\end{array}$ & $\begin{array}{c}\text { Pêra } \\
\text { orange leaves }\end{array}$ & $\begin{array}{c}\text { Ponkan } \\
\text { tangerine } \\
\text { (B-52-01) }\end{array}$ & $\begin{array}{c}\text { Ponkan } \\
\text { tangerine } \\
\text { (B-62-04) }\end{array}$ & $\mathrm{CV}$ \\
\hline $\mathrm{A}$ & - & - & - & - & - & - & - \\
$\mathrm{B}$ & - & $13.9 \times 10^{5} \mathrm{cA}$ & - & - & - & $17.2 \times 10^{5} \mathrm{dA}$ & $13.93 \%$ \\
$\mathrm{C}$ & - & $2.8 \times 10^{5} \mathrm{aA}$ & - & - & - & $4.2 \times 10^{5} \mathrm{bB}$ & $13.40 \%$ \\
$\mathrm{D}$ & - & $3.0 \times 10^{5} \mathrm{aA}$ & - & - & - & $5.4 \times 10^{5} \mathrm{bB}$ & $8.86 \%$ \\
$\mathrm{E}$ & - & $1.4 \times 10^{5} \mathrm{aA}$ & - & - & - & $1.4 \times 10^{5} \mathrm{aA}$ & $13.21 \%$ \\
$\mathrm{~F}$ & - & - & - & - & - & - & - \\
$\mathrm{G}$ & - & $10.6 \times 10^{5} \mathrm{bA}$ & - & - & - & $10.1 \times 10^{5} \mathrm{cA}$ & $11.63 \%$ \\
$\mathrm{H}$ & - & $10.7 \times 10^{5} \mathrm{bA}$ & - & - & - & $10.1 \times 10^{5} \mathrm{cA}$ & $16.52 \%$ \\
$\mathrm{I}$ & - & $10.0 \times 10^{5} \mathrm{bA}$ & - & - & - & $9.6 \times 10^{5} \mathrm{cA}$ & $4.98 \%$ \\
$\mathrm{CV}$ & - & $17.61 \%$ & - & - & - & $12.24 \%$ & - \\
\hline
\end{tabular}

* Means of four replications (4 Petri dishes/treatment, and to each Petri dish, one counting with 8 replications using the Neubauer chamber) with the same small and capital letter in a column and line do not differ significantly $(P \leq 0.05)$ according to the Scott-Knott $(22)$ calculations, respectively.

identification was obtained with the isolate obtained from Murcott tangor (A1-03-04) under mycelium stress technique conditions, which produced $2.8-3.0 \times 10^{5}$ conidia $\mathrm{mL}^{-1}$.

The length and width of $A$. alternata conidia from Murcott tangor (A1-03-04) and Ponkan tangerine (B-62-04) fruits were measured (Table 4). There were few differences in the size of conidia proceeding from both the host tissue and in the methodology (C).

\section{DISCUSSION}

The absence of conidia in methodology (A) was not surprising, given that a notable conidia production of $A$. alternata is difficult without interference of physic factors (3) or an addition of specific synthetic components at culture medium (24). Concerning methodology $(\mathrm{F})$, the literature shows that to some fungi, such as Colletotrichum lindemuthianum and Fusarium spp., the conidia and macroconidia were obtained with insertion of bean pod and carnation leaves into culture medium, respectively $(6,10)$. Similarly, in a specific case, Vakalounakis (29) obtained a high number of Alternaria solani Sorauer conidia through the use of mycelial agar plugs removed from the border of fungal colonies 4 day old and put on Solanaceae leaves. To test this methodology, agar plugs were removed from the border of 4-5 day old colonies, but conidia production was not observed. Also, Timmer et al., (27) observed that Alternaria sp. sporulation was not observed on killed tissues.

The isolates from Cravo lemon (B-66-01), Pêra orange fruits (B-52-09) and leaves (A-07-01) and Ponkan tangerine (B-52-01)
Table 4. Length and width, beak length, and total length of Alternaria alternata conidia from Murcott tangor and Ponkan tangerine (B-62-04) fruits, after the use of methodology (C), in the in vitro conidia production.

\begin{tabular}{ccc}
\hline & \multicolumn{2}{c}{ Isolated } \\
\cline { 2 - 3 } Variable studied* & $\begin{array}{c}\text { Murcott tangor } \\
\text { (A1-03-04) }\end{array}$ & $\begin{array}{c}\text { Ponkan tangerine } \\
\text { (B-62-04) }\end{array}$ \\
\hline Length $(\mu m)$ & & \\
Variation & $22.5-35.0$ & $17.5-32.5$ \\
Average & 28.2 & 22.8 \\
CV & $3.7 \%$ & $3.0 \%$ \\
Width $(\mu m)$ & & \\
Variation & $5.0-10.0$ & $5.0-12.5$ \\
Average & 7.8 & 8.0 \\
CV & $1.6 \%$ & $1.8 \%$ \\
Beak $(\mu \mathrm{m})$ & & \\
Variation & $2.5-7.5$ & $2.5-9.5$ \\
Average & 5.1 & 4.4 \\
CV & $1.7 \%$ & $2.0 \%$ \\
Total length $(\mu m)$ & & \\
Variation & $22.5-40.0$ & $20.0-35.0$ \\
Average & 31.8 & 25.4 \\
CV & $5.1 \%$ & $4.0 \%$ \\
\hline Conidia with beak & $70 \%$ & $66 \%$ \\
\hline
\end{tabular}

* The key structures of the fungus were measured thirty times; $\mathrm{CV}$ : coefficient of variability. 
did not produce any conidia (Table 3). A possible explanation for these results could be that these isolates are not able to produce conidia in nature (1). The virulence level and growth conditions of the isolate can be related with conidia production, because they affect the potential inoculum of A. alternata (12). These authors obtained the most virulent conidia on PDA medium at $28^{\circ} \mathrm{C}$ under constant black fluorescent NUV lamp for 4 weeks.

Shahin and Shepard (23) and Teixeira et al., (25) observed that black fluorescent NUV lamp is necessary for growth and sporulation of Alternaria spp. Furthermore, Ungaro (28) classified A. alternata sporulation as small (less than $10^{4}$ conidia $\left.\mathrm{mL}^{-1}\right)$, medium $\left(10^{4}-10^{6}\right.$ conidia $\left.\mathrm{mL}^{-1}\right)$ and abundant (more than $10^{6}$ conidia $\left.\mathrm{mL}^{-1}\right)$. The methodologies applied to conidia production to be used in Murcott tangor (A1-03-04) and Ponkan tangerine (B-62-04) isolates, including (C), (D) and (E), can be considered as producing a medium quantity of conidia, except (B), $(\mathrm{G}),(\mathrm{H})$ and $(\mathrm{I})$, that produced an abundant quantity (Table $3)$. Thus, all methodologies that resulted in medium and abundant conidia production were considered to be satisfactory, but (C) and (D) produced the ideal quantity of conidia necessary for in vitro assays on ELISA plates, which need 2.6-3.0 $\times 10^{5}$ conidia $\mathrm{mL}^{-1}(21)$. On the other hand, according with Colturato (5), the methodologies (B), (G), (H) and (I) produced a conidia number adequate for in vivo tests, which need $10^{6}$ conidia $\mathrm{mL}^{-1}$, such as pathogenicity assay.

It is also worth mentioning that, although without any conidia production, the isolates B-66-01 (Cravo lemon), B-52-09 and A07-01 (Pêra orange) and B-52-01 (Ponkan tangerine) showed clear symptoms in the pathogenicity assay (Fig. 1). A possible explanation for these results could rely on the fact that in the fields, lesions on fruit appear to require more time to produce conidia than in the leaves (20). Furthermore, Whiteside (32) noted that, in field, sporulation was more abundant on leaves than on fruit. Even without any conidia production, symptoms on fruit can be verified. Low sporulation was observed by Reis and Goes (20), 60 days after lesion development, and lesions may be able to produce a few conidia that would serve as primary inoculum in the spring. Also, these authors verified that the sporulation only began about 10 days after symptom development and continued for about the next 40 days, but about 60 days after symptom appearance, conidia were no longer produced (20).

Surprisingly, the methodology (E) of this work showed that cold shock seems not to be effective in the sporulation. Such behavior is not in accordance with the work of Prasad et al., (17), wherein Alternaria solani showed sporulation under photoperiod of 12 hours and thermal shock at $4^{\circ} \mathrm{C}$. However the cultures of Prasad were dipped in cold water $\left(4^{\circ} \mathrm{C}\right)$ for $4 \mathrm{~min}$ only. In opposition, the objective of thermal shock in this work was to expose the colonies at minimal temperature for longer time and to evaluate the sporulation after subsequently stress of the colonies. Another question relies on temperature, whereas Colturato (5) revealed that the best temperature for $A$. alternata from Murcott tangor to conidia production was $28^{\circ} \mathrm{C}$, and not $25^{\circ} \mathrm{C}$. Nevertheless high conidia number was obtained at $25^{\circ} \mathrm{C}$ in this work (Table 3). This author observed that, at $25^{\circ} \mathrm{C}$, there is a larger mycelial growth. Although Lukens and Horsfall (11) have reported that the mycelium injury was not benefic to Alternaria spp. conidiophores production, this study showed that the introduction of a needle into PDA culture medium at 4 mm deep aiming to cut the fungal mycelium, was advantageous for conidia production. Today there is not enough information about studies for in vitro conidia production. Thus, Charlton (4) observed that $A$. solani fungal colonies, when not injured, were difficult to remove conidia.

According to the isolate, the methodology applied can be better adjusted to conidia production. An example was the methodologies (C) and (D), which showed higher conidial production to Ponkan tangerine (B-62-04) than Murcott tangor (A1-03-04) (Table 3). This behavior is observed in methodologies that are able to produce lower quantity of conidia.

Regarding length and width of conidia (Table 4), there are not differences among the dimensions of conidia from $A$. alternata coming from different hosts. It is a confirmation that the isolates are from same species, A. alternata (13). The morphology of conidia, produced under in vitro conditions, is in accordance with Ellis (8), who found out that the length was $20-63 \mu \mathrm{m}$ and the width was $9-18 \mu \mathrm{m}$ for A. alternata.

With the improvements of methodologies for conidia production in A. alternata obtained in the present study, it is now possible to obtain conidia at suitable quantity to several purposes, such as to identify fungitoxic substances on ELISA plates and Petri dishes, without using cold shock, black fluorescent NUV lamp and addition of vegetable tissue on the culture medium to stimulate conidia production. Also, these methodologies can serve as alternatives to induce the sporulation of other Alternaria spp. and fungi.

\section{ACKNOWLEDGEMENTS}

The authors thank CNPq (Conselho Nacional de Desenvolvimento Científico e Tecnológico) for a master fellowship and the Doctor Cristiano Souza Lima for revision and suggestion to this paper.

\section{RESUMO}

\section{Comparação de metodologias para produção de conídios por Alternaria alternata do citros}

A produção de conídios consiste em problema no estudo de Alternaria alternata do citros. Assim, este estudo objetivou comparar metodologias existentes para a produção de conídios 
de A. alternata por dois isolados de tangerina Ponkan, um de limão Cravo, dois de laranja Pêra e um de tangor Murcott. As metodologias empregadas foram a produção de conídios com 12 e 24 horas sob luz branca, avaliação com 24 e 48 horas após estressamento do micélio do fungo, choque térmico com imediato estressamento do micélio e avaliação com 24 horas, produção de conídios pelo emprego de tecido vegetal sadio e o emprego de luz negra ultravioleta. Produção satisfatória de conídios foi obtida com o isolado de A. alternata de tangor Murcott, a qual foi de 2,8 $\times 10^{5}$ conídios $\mathrm{mL}^{-1}$, mediante emprego da técnica de estressamento da colônia e cultivo do fungo por 24 horas. Os empregos de luz branca $(24 \mathrm{~h}$ ) e negra ultravioleta promoveram expressiva produção de conídios por um isolado de tangerina Ponkan, a qual foi de $17,2 \times 10^{5}$ e $10,1 \times 10^{5}$ conidios $\mathrm{mL}^{-1}$ e por outro de tangor Murcott, a qual foi de $13,9 \times 10^{5} \mathrm{e} 10,1$ x $10^{5}$ conídios $\mathrm{mL}^{-1}$, respectivamente. As outras metodologias analisadas neste estudo não foram capazes de induzir a produção de conídios em quantidade satisfatória. Com o emprego das técnicas de estressamento do micélio e a utilização de luz branca $(24 \mathrm{~h})$ e negra ultravioleta, tornou-se possível obter quantidades de conídios suficientes para serem utilizadas em testes in vitro (detecção de substâncias fungitóxicas) e in vivo (testes de patogenicidade), respectivamente.

Palavras chave: Mancha marrom de alternaria, estressamento do micélio, tangor Murcott, tangerina Ponkan, luz negra ultravioleta.

\section{REFERENCES}

1. Babu, R.M.; Sajeena, A.; Seetharaman, K. (2004). Solid substrate for production of Alternaria alternata conidia: a potential mycoherbicide for the control of Eichhornia crassipes (water hyacinth). Weed Res., 44 (4), 298-304.

2. Balbi-Peña, M.I.; Becker, A.; Stangarlin, J.R.; Franzener, G.; Lopes, M.C.; Schwan-Estrada, K.R.F. (2006). Controle de Alternaria solani em tomateiro por extratos de Curcuma longa e Curcumina - I. Avaliação in vitro. Fitopatol. Bras., 31 (3), 310-314.

3. Bóveda, R.R.M. (1986). Morfologia, patogenicidade, esporulação e sensibilidade a fungicidas in vitro de Alternaria solani (Ell. e Mart.) Jones e Grout e Alternaria alternata (Fr.) Keissler de solanáceas. 106 p. Dissertação de Mestrado - Escola Superior de Agricultura Luiz de Queiroz, Piracicaba.

4. Charlton, K.M. (1953). The sporulation of Alternaria solani in culture. Transactions British Mycol. Society, 36, 349-355.

5. Colturato, A.B. (2006). Efeito do meio de cultura, temperatura, fotoperíodo e fungicidas no crescimento micelial e no controle de Alternaria alternata f. sp. citri, causador da mancha marrom do tangor Murcote. 53 p. Dissertação de Mestrado - Faculdade de Ciências Agronômicas da Universidade Estadual Paulista, Botucatu.

6. Dalla Pria, M.; Amorim, L.; Bergamin Filho, A. (2003). Quantificação dos componentes monocíclicos da antracnose do feijoeiro. Fitopatol. Bras., 28 (4), 401-407.

7. Dantas, S.A.F.; Oliveira, S.M.A.; Michereff, S.J.; Nascimento, L.C.; Gurgel, L.M.S.; Pessoa, W.R.L.S. (2003). Doenças Fúngicas PósColheita em Mamões e Laranjas Comercializados na Central de Abastecimento do Recife. Fitopatol. Bras., 28 (5), 528-533.

8. Ellis, M.B. (1993). Dematiaceous Hyphomycetes. CAB international, Oxon, 608 p.
9. Goes, A.; Montes de Oca, A.G.; Reis, R.F. (2001). Ocurrencia de la mancha de Alternaria en mandarina Dancy en el estado de Rio de Janeiro. Fitopatol. Bras., 26, 386.

10. Leslie, J.F.; Summerell, B.A. (2006). The Fusarium Laboratory Manual. Blackwell Publishing Asia, Ames (Iowa, USA), 388 p.

11. Lukens, R.J.; Horsfall, J.G. (1973). Process of sporulation in Alternaria solani and their response to inhibitors. Phytopathol., 63, 176-182.

12. Masangkay, R.F.; Paulitz, T.C.; Hallett, S.G.; Watson, A.K. (2000). Characterization of sporulation of Alternaria alternata f. sp sphenocleae. Biocontrol Sci. Technol., 10 (4), 385-397.

13. Peever, T.L.; Carpenter-Boggs, L.; Timmer, L.W.; Carris, L.M.; Bhatia, A. (2005). Citrus black rot is caused by phylogenetically distinct lineages of Alternaria alternata. Phytopathol., 95, 512 518.

14. Peever, T.L.; Su, G.; Carpenter-Boggs, L.; Timmer, L.W. (2004). Molecular systematics of citrus-associated Alternaria spp. Mycologia, 96, 119-134.

15. Peres, N.A.R.; Agostini, J.P.; Timmer, L.W. (2003). Outbreaks of Alternaria brown spot of citrus in Brazil and Argentina. Plant Disease, 87 (8), 750.

16. Peres, N.A.; Timmer, L.W. (2006). Evaluation of the Alter-Rater model for spray timing for control of Alternaria brown spot on Murcott tangor in Brazil. Crop Protec., 25, 454-460.

17. Prasad, B.; Dutt, B.L.; Nagaich, B.B. (1973). Inducing sporulation in Alternaria solani I. Effect of water treatment. Mycopathol. Mycol. Appl., 49, 141-146.

18. Prates, H.S. (2007). Mancha de alternaria das tangerinas. Available at: http://www.cati.sp.gov.br/novacati/tecnologias/ doencas_de_plantas/alternaria/mancha_alternaria.htm. Accessed 27 Feb 2007.

19. Prusky, D.; Kobiler, I.; Akerman, M.; Miyara, I. (2006). Effect of acidic solutions and acidic prochloraz on the control of postharvest decay caused by Alternaria alternata in mango and persimmon fruit. Postharvest Biol. Technol., 42, 134-141.

20. Reis, R.F.; Goes, A. (2005). Effect of lesion age, humidity, and fungicide application on sporulation of Alternaria alternata, the cause of brown spot of tangerine. Plant Disease, 90 (8), 1051-1054.

21. Saks, Y.; Barkai-Golan, R. (1995). Aloe Vera gel activity against plant pathogenic fungi. Postharvest Biol. Technol., 6, 159-165.

22. Scott, A.J.; Knott, M.A. (1974). A cluster analyses method for grouping means in the analyses of variance. Biometrics, 30 (3), 502512.

23. Shahin, E.A.; Sheppard, J.F. (1979). An efficient technique for inducing profuse sporulation of Alternaria species. Phytopathol., 69, 618-620.

24. Silva, C.M.M.S.; Melo, I.S. (1999). Requisitos nutricionais para o fungo Alternaria alternata. Pesq. Agropec. Bras., 34, 499-503.

25. Teixeira, H.; Arias, S.M.S.; Chitarra, L.G.; Machado, J.C. (2002). Eficiência comparativa de lâmpadas fluorescentes na detecção e quantificação de fungos em sementes. Ciênc. Agrotec., 26 (2), 259268.

26. Timmer, L.W.; Peever, T.L.; Solel, Z.; Akimitsu, K. (2003). Alternaria diseases of citrus-novel pathosystems. Phytopathol. Mediterr., 42, 99-112.

27. Timmer, L.W.; Solel, Z.; Gottwald, T.R.; Ibanez, A.M.; Zitko, S.E. (1998). Environmental factors affecting production, release, and field populations of conidia of Alternaria alternata, the cause of brown spot of citrus. Phytopathol., 88 (11), 1218-1223.

28. Ungaro, M.R.G. (1981). Sensibilidade de Alternaria alternata (Fr.) Keissler a três fungicidas. 67 p. Dissertação de Mestrado - Escola Superior de Agricultura Luiz de Queiroz, Piracicaba.

29. Vakalounakis, D.J. (1982). An efficient and simple technique for inducing profuse sporulation in Alternaria solani. Phytopathol. Mediterr., 21 (43), 89-90. 
30. Verzignassi, J.R.; Vida, J.B.; Homechin, M. (1997). Ocorrência e transmissão de Alternaria steviae e A. alternata em sementes de Stevia rebaudiana (bert.) Bertoni. Rev. Bras. Sementes, 19 (2), 283-287.

31. Vicent, A.; Badal J.; Asensi, M.J.; Sanz, N.; Armengol, J.; Garc'iaJim'enez, J. (2004). Laboratory evaluation of citrus cultivars susceptibility and influence of fruit size on Fortune mandarin to infection by Alternaria alternata pv. citri. Eur. J. Plant Pathol., $110,245-251$.

32. Whiteside, J.O. (1998). Alternaria brown spot of mandarins. In: Whiteside, J.O.; Garnsey, S.M.; Timmer, L.M. (eds). Compendium of citrus diseases. American Phytopatological Society, Saint Paul, p. 8 . 